\title{
Expression of Ethylene Biosynthetic Genes in the Gynoecium and Receptacle Associated With Sepal Abscission During Senescence in Delphinium Grandiflorum
}

\section{Mitsutoshi Okamoto}

Ehime Research Institute of Agriculture, Forestry and Fisheries

\section{Tomoko Niki}

Institute of Vegetable and Floriculture Science, NARO

Mirai Azuma

Nihon University: Nihon Daigaku

Kenichi Shibuya

Institute of Vegetable and Floriculture Science, NARO

Kazuo Ichimura ( $\square$ ichimuraphpkazuo@gmail.com )

Institute of Vegetable and Floriculture Science, NARO https://orcid.org/0000-0002-0941-9671

\section{Research Article}

Keywords: 1-Aminocyclopropane-1-carboxylic acid synthase (ACS), 1-Aminocyclopropane-1-carboxylic acid oxidase (ACO), Ethylene exposure, Pollination

Posted Date: December 21st, 2021

DOI: https://doi.org/10.21203/rs.3.rs-975326/v1

License: (c) (i) This work is licensed under a Creative Commons Attribution 4.0 International License.

Read Full License 


\section{Abstract}

Delphinium flowers are highly sensitive to ethylene and its sepals abscise during senescence, which is associated with increases in 1-aminocyclopropane-1-carboxylic acid (ACC) synthase (ACS) and ACC oxidase (ACO) activities and ethylene production in gynoecium and receptacle. Three ACS genes (DgACS1, DgACS2, and DgACS3) and three ACO genes ( $D g A C O 1, D g A C O 2$, and $D g A C O 3$ ) were cloned from Delphinium grandiflorum $\mathrm{cv}$. Super Grand Blue. To investigate the contribution of these genes to ethylene production, their expression was analyzed in these genes in the gynoecium and receptacle during natural senescence and following ethylene exposure and pollination. Ethylene production in the gynoecium and receptacle increased during natural flower senescence. The transcript levels of the ACS and $A C O$ genes in these organs, excluding DgACS2 in the receptacle, increased during senescence. Exposure to ethylene accelerated sepal abscission and more strongly increased ethylene production in the receptacle than in the gynoecium. DgACS1 transcript levels in the gynoecium and DgACS2 and DgACO3 transcript levels in the receptacle were increased by ethylene exposure. Pollination accelerated sepal abscission and increased ethylene production in the gynoecium and receptacle. Pollination slightly affected $A C S$ and $A C O$ transcript levels in the gynoecium, whereas $D g A C O 3$ transcript level in the receptacle were markedly increased. These results reveal that $A C S$ and $A C O$ gene expression is differently regulated in the gynoecium and receptacle, and some of these genes are more strongly upregulated by ethylene exposure and pollination in the receptacle than in the gynoecium, suggesting the significance of the receptacle to sepal abscission.

\section{Introduction}

The phytohormone ethylene plays an important role in various stages of plant growth and development, including senescence. Exposure to ethylene accelerates the senescence of flowers in many species, and the primary symptom of senescence induced by ethylene is petal wilting or petal (sepal) abscission (Woltering and van Doorn 1988). In many ethylene-sensitive flowers, such as carnation (Nichols 1968) and Eustoma grandiflorum (Ichimura et al. 1998), the petals wilt in response to ethylene exposure. In Digitalis (Stead and Moore 1983), geranium (Hilioti et al. 2000), and torenia flowers (Goto et al. 1999), petals abscise upon exposure to ethylene. In these flowers, ethylene production in the gynoecium or pistil increases with the progression of flower senescence. However, this finding is not observed in the petals (Stead and Moore 1983; Goto et al. 1999; Hilioti et al. 2000). Therefore, ethylene produced by the gynoecium has been considered responsible for petal abscission.

Pollination accelerates petal wilting in many ethylene-sensitive flowers, including carnation (Jones and Woodson 1997), petunia (Gillisen and Hoekstra 1984; Whitehead et al. 1984), and gentian (ShimizuYumoto and Ichimura 2012). Similarly, pollination induces petal abscission in Digitalis (Stead and Moore 1979, 1983), geranium (Clark et al. 1997), and torenia (Goto et al. 1999). Pollination induces climactericlike increases in ethylene production, and ethylene inhibitors suppress pollination-induced senescence in many plants, including orchids (O'Neill et al. 1993; Porat et al. 1995), E. grandiflorum (Ichimura and Goto 
2000), and torenia (Goto et al. 1999), indicating that pollination-induced petal senescence is regulated by ethylene.

The biosynthetic pathway for ethylene in higher plants has been established. 1-Aminocyclopropane-1carboxylic acid (ACC), the precursor of ethylene, is produced by the conversion of S-adenosyl-I-methionine (SAM) by ACC synthase (ACS). ACC is converted to ethylene, carbon dioxide, and $\mathrm{HCN}$ by ACC oxidase (ACO). ACS is generally considered to be a rate-limiting enzyme for ethylene biosynthesis in plants because ACO activity is constitutive in many species (Yang and Hoffman 1984; Kende 1993). However, ACO is important for ethylene biosynthesis in some examples, including fruit maturation (Nakatsuka et al. 1998) and flower senescence (Tang et al. 1994). In cut carnation flowers, the biosynthesis of ethylene is regulated by the activities of ACS and ACO (Woodson et al. 1992; Woltering et al. 1993; Lee et al. 1997). ACS and ACO proteins are encoded by multi-gene families (Argueso et al. 2007; Lin et al. 2009), and these genes are differently regulated in response to developmental and environmental factors (Lin et al. 2009). Expression analyses of $A C S$ and $A C O$ genes have been performed in floral organs, using carnation (Jones and Woodson 1997, 1999; Jones 2003), petunia (Tang et al. 1994), tomato (Llop-Tous et al. 2000), and rose (Xue et al. 2008). In carnation flowers, three ACS genes, namely, DCACS1, DCACS2, and DCACS3, have been cloned, and their expression is differentially regulated (Jones and Woodson 1999). In tomato flowers, SIACS2 is upregulated by pollination (Llop-Tous et al. 2000). However, few studies have analyzed $A C S$ and $A C O$ gene expression in flowers displaying petal abscission. In geranium, $A C S$ and $A C O$ gene expression has only been semi-quantified using RNA gel blot analysis (Clark et al. 1997).

Delphinium has long spikes with flowers of various colors, such as white, blue, and purple. The genus Delphinium consists of more than 300 species, and $D$. elatum, $D$. grandiflorum and $D . \times$ belladonna, which is a hybrid of $D$. elatum and $D$. grandiflorum, are widely produced as ornamental plants. Instead of $D . \times$ belladonna, which was mainly produced approximately a decade ago, $D$. grandiflorum is widely produced for cut flowers. Delphinium flowers are sensitive to ethylene, and their sepals rapidly abscise upon exposure (Woltering and van Doorn 1988; Ichimura et al. 2000), which is accompanied by signs of programmed cell death (Yamada et al. 2007). In Delphinium, sepals and petals are directly connected to the receptacle, but not to the gynoecium. Thus, ethylene produced by the receptacle should directly induce the abscission of the sepals (Ichimura et al. 2009). Ethylene production in the gynoecium and receptacle increases during flower senescence, but that in the other floral organs including petals and sepals, does not increase (Ichimura et al. 2009). ACS and ACO activity in the gynoecium and receptacle increases during flower senescence (Ichimura et al. 2009). Although genes for ethylene receptors and signal transduction components have been identified in D. elatum (Kuroda et al. 2003, 2004) and D. $\times$ belladonna (Tanase and Ichimura 2006), ACS and ACO genes have not yet been cloned in Delphinium. The quantification of $A C S$ and $A C O$ gene expression will help to clarify the effects of ethylene on sepal abscission.

In the present study, we cloned $A C S$ and $A C O$ genes and determined their nucleotide sequences in $D$. grandiflorum. Furthermore, we investigated their expression of $A C S$ and $A C O$ genes in the gynoecium and 
receptacle during natural senescence, following exposure to ethylene, and after pollination in cut $D$. grandiflorum flowers.

\section{Materials And Methods Plant materials}

Delphinium grandiflorum cv. Super Grand Blue (Miyoshi, Tokyo, Japan) was grown in a greenhouse under natural day length conditions with temperatures ranging from $15^{\circ} \mathrm{C}$ to $25^{\circ} \mathrm{C}$. On the day of anthesis, flowers with a peduncles of $3 \mathrm{~cm}$ in length were cut from the middle region of the flower spikes. Cut peduncles were placed in a vessel with distilled water within $1 \mathrm{~h}$ after harvest and used for all subsequent experiments. Cut flowers were held at $23^{\circ} \mathrm{C}, 70 \%$ relative humidity, and $10 \mu \mathrm{mol} \mathrm{m}^{-2} \mathrm{~s}^{-1}$ irradiance using cool-white fluorescence lamps under a 12-h photoperiod.

The morphology of $D$. grandiflorum flowers is shown in Figure 1. The spike features approximately 10 flowers (Fig. 1A), whereas petals lack in the flower, unlike other Delphinium species (Fig. 1B). Its gynoecium is covered with stamens (Fig. 1C). The receptacle lies below the gynoecium, and sepals are attached to the receptacle (Fig. 1D).

\section{Ethylene treatment}

The cut flowers were placed in individual vessels containing distilled water and then transferred to a 70-L transparent acrylic box fitted with a septum, through which ethylene was introduced to achieve a concentration of $10 \mu \mathrm{L}^{-1}$. The box was kept at $23^{\circ} \mathrm{C}$ under a $12 \mathrm{~h}$-photoperiod with $10 \mu \mathrm{mol} \mathrm{m} \mathrm{m}^{-2} \mathrm{~s}^{-1}$ irradiance from cool-white fluorescent lamps for $24 \mathrm{~h}$. After exposure to ethylene, flowers were removed from the chamber and kept under the same temperature and lighting conditions as above.

\section{Pollination}

In the greenhouse, stamens were removed on the day of anthesis, and the individual flowers were enveloped with paper bags to prevent pollination. The stigma matured approximately 4 days after emasculation. Then, the flowers were cut from the plant, transported to the laboratory, and placed in water. The flowers were pollinated with fresh pollen collected from the same cultivar. The flowers were held under the aforementioned environmental conditions as above.

\section{Observation of the pollen tube growth}

Gynoecia were removed from pollinated flowers $6,12,24$, or $48 \mathrm{~h}$ after pollination and immersed in FAA solution (formalin, $80 \%$ ethanol, acetic acid, 1:8:1 (v/v)). Gynoecia were macerated in $8 \mathrm{M} \mathrm{NaOH}$ for $24 \mathrm{~h}$, rinsed in tap water for $1 \mathrm{~h}$ and stained with $0.1 \%$ aniline blue in $0.1 \mathrm{M} \mathrm{K}_{3} \mathrm{PO}_{4}$. Pollen tubes were observed microscopically under incident ultraviolet illumination.

\section{Measurement of ethylene production}


Gynoecia and receptacles were individually placed in test tubes $(14.8 \mathrm{~mL})$. They were sealed and maintained at $23^{\circ} \mathrm{C}$. One hour later, a $1-\mathrm{mL}$ gas sample was withdrawn using a syringe and used to determine the ethylene concentration using a gas-chromatograph (GC-14B, Shimadzu, Kyoto, Japan) equipped with an alumina column and a flame ionization detector. The results of ethylene production were expressed on a fresh weight basis.

\section{RNA extraction}

Frozen gynoecium and receptacle $(0.1 \mathrm{~g} \mathrm{FW})$ were powdered under liquid nitrogen by a Shake Master Auto (Bio medical science, Tokyo, Japan) and added to $450 \mu \mathrm{L}$ of RLT buffer including $1 \% 2$ -

mercaptoethanol. The mixture was incubated at $56^{\circ} \mathrm{C}$ for $1 \mathrm{~min}$. Total RNA was extracted using RNeasy Plant Mini kit (QIAGEN, Hilden, Germany) according to the manufacture's manual with some modification.

\section{First strand CDNA and PCR amplification}

Synthesis of cDNA was carried out with random hexamer primers using the Invitrogen SuperScript III firststrand synthesis system for RT-PCR (Thermo Fisher Scientific, Waltham, MA, USA). To clone the partiallength of the target CDNA, degenerate primer pairs were designed based on highly conserved regions of the ACS, ACO or Actin genes: for ACS, 5》-CARATGGGIYTIGCIGARAAYCA -3囚 (forward) and 5》-

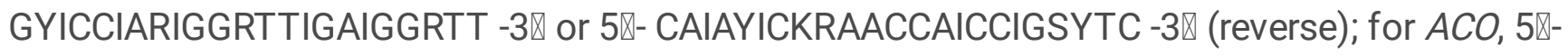

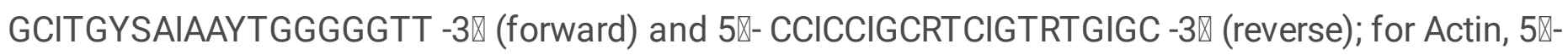
TGGGAYGAYATGGARAARATHTGG -3区 (forward) and 5囚- CCDATIGTDATIACYTGICC -3囚 (reverse). PCR reactions were performed with Ex Taq (Takara bio, Kusatsu, Japan) and cycled 30 times at $94^{\circ} \mathrm{C}$ for $30 \mathrm{~s}$, $50^{\circ} \mathrm{C}$ for $30 \mathrm{~s}$ and $72^{\circ} \mathrm{C}$ for $1 \mathrm{~min}$. PCR products were separated electrophoretically onto $1 \%(\mathrm{w} / \mathrm{v})$ agarose gel, stained with GelRadTM (Biotium, Fremont, CA, USA) and candidate bands were excised. The excised bands were purified with a Wizard Plus SV Minipreps DNA Purification System (Promega, San Luis Obispo, CA, USA) and subcloned into the pGEM-TeasyVecter (Promega) according to the manufacture's manual.

To clone the 3 ' and 5 ' ends of the target CDNA, RACE-PCR was performed using 3'-Full RACE Core Set (Takara bio) and CapFishing Full-Length cDNA Premix Kit (Seegene, Seoul, Korea). Specific primers were designed based on the sequence data obtained from the partial-length of the target CDNA (Table S1). PCR products were purified and sub-cloned into the pGEM-TeasyVecter. The full length cDNA was cloned and the DNA sequence was confirmed using specific primers.

\section{Determination of nucleotide sequence}

Sequencing of DNA was performed using an Applied Biosystems ABI Prism DNA sequencer (Model 377; Thermo Fisher Scientific) and the Applied Biosystems Big Dye Terminator v.3.1 Cycle Sequencing Kit (Thermo Fisher Scientific), employed with both T7HT and M3RP universal primers. Sequence analysis was performed using ClustalW2 (European Bioinformatics Institute, http://www.ebi.ac.uk/Tools/msa/clustalw2/). Homology was obtained by comparing the sequenced clones with the existing translated DNA in the database of the National Center for Biotechnology 
Information BLAST algorithm (http://www.ncbi.nlm.nih.gov/nucleotide/). Phylogenic analysis was performed with Phylogeny.fr (http://www.phylogeny.fr/).

\section{Preparation of total RNA and real-time RT-PCR}

Gynoecia and receptacles were collected from three individual flowers. Total RNA was isolated using RNeasy plant mini kit (QIAGEN). Genomic DNA included in the RNA sample was digested with the RNasefree DNase set. Quality and quantity of RNA were checked using the NanoDrop ND-1000 spectrophotometer (Thermo Fisher Scientific). Synthesis of cDNA was performed with random hexamer primers using the Invitrogen SuperScriptlll first-strand system for RT-PCR. The following primers were used for real-time RT-PCR: for DgACS1, 5囚-TGGACAACGAGACGATGGAG-3囚 (forward) and 5囚GAAGCTGAGACGGAGGTTGTT-3囚 (reverse); for DgACS2, 5》-GACTCCTCATACTCCTATCCCACAG-3》 (forward) and 5囚-ACCTCCTGGTGTTTATTTCACAGTC-3区 (reverse); for DgACS3, 5囚-

TTTTGCCAACATGAGCCAAC-3区 (forward) and 5囚-TTGTGGCATCTTCTTTTCTCCA-3区 (reverse); for

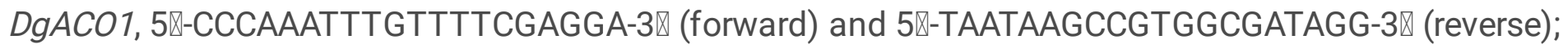

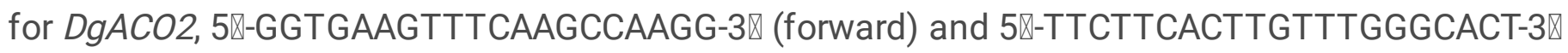
(reverse); for DgACO3, 5囚-GGGTGAAGTTTCAAGCCAAG-3囚 (forward) and 5囚-CAATTTGCTGACCCATCTGA-

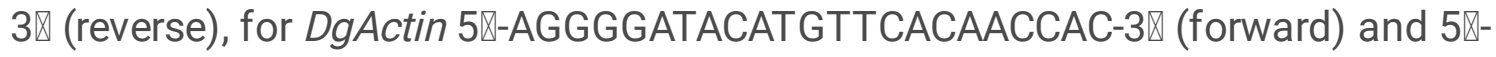

TTTCAAGCTCCTGCTCATAGTCC-3囚 (reverse).

PCR reactions were performed with Thermal Cycler Dice Real Time System (Takara bio), using SYBR Premix Ex Taq II (Perfect Real Time, Takara bio). Each reaction was performed using $0.8 \mu \mathrm{L}$ aliquot of 20 $\mu \mathrm{L} \mathrm{cDNA}$ solution derived from $1 \mu \mathrm{g}$ of total RNA. The following program was applied: initial polymerase activation at $95^{\circ} \mathrm{C}$ for $30 \mathrm{~s}$; then 40 cycles at $95^{\circ} \mathrm{C}$ for $5 \mathrm{~s}, 60^{\circ} \mathrm{C}$ for $30 \mathrm{~s}$. The specificity of the PCR was checked using a heat dissociation protocol (from $95^{\circ} \mathrm{C}$ to $60^{\circ} \mathrm{C}$ ) after the final cycle.

The absolute transcript level was determined by the second derivative maximum method (Luu-The et al., 2005) using a dilution series of plasmid DNA containing target sequence as external standards. To standardize the data, the ratio between the absolute transcript level of the target gene and the control gene was calculated for each sample.

\section{Results}

\section{Cloning and nucleotide sequences of ACS genes}

Three ACS genes were cloned and designated DgACS1, DgACS2 and DgACS3 and deposited in the DDBJ with accession nos LC603027, LC603028, and LC603029, respectively. The CDNAs of these genes were 1901,1739 , and 1721 bp in length, respectively. The predicted proteins consisted of 486 amino acids for DgACS1, 485 amino acids for DgACS2, and 444 amino acids for DgACS3. The amino acid homologies were $80.9 \%$ between DgACS1 and DgACS2, $55.8 \%$ between DgACS1 and DgACS3, and $53.2 \%$ between DgACS2 and DgACS3. Seven conserved domains were observed in the three genes (Supplementary Fig. S1). 
ACS proteins have been categorized into three types based on the sequences of C-terminal region (Lin et al. 2009). Type 1 ACS proteins have been revealed to be phosphorylated by the mitogen-activated protein kinase (MAPK) and calcium-dependent protein kinase (CDPK), whereas type 2 ACS proteins only have CDPK site. Type 3 proteins lack these two sites for phosphorylation. Based on these criteria, the predicted proteins of DgACS1 and DgACS2 belong to type 1, whereas that of DgACS3 belongs to type 3 (Supplementary Fig. S2).

\section{Cloning and nucleotide sequences of ACO genes}

Three $A C O$ genes were cloned and designated $D g A C O 1, D g A C O 2$ and $D g A C O 3$, and deposited in the DDBJ with accession nos LC603030, LC603031, and LC603032, respectively. The CDNAs of these genes were 1182,1159 , and $1072 \mathrm{bp}$ in length, respectively. The predicted proteins consisted of 317 amino acids for DgAC01, 317 amino acids for DgACO2 and 319 amino acids for DgACO3 (Supplementary Fig. S3). The amino acid homologies were $78.6 \%$ between DgAC01 and DgACO2, $78.6 \%$ between DgACO1 and DgACO3, and $94 \%$ between DgACO2 and DgACO3. Twelve amino acids, which are known to be conserved in ACO proteins (Do et al. 2005; Momonoi et al. 2007; Wang and Woodson 1991), were conserved in DgAC01, DgACO2, and DgACO3.

The phylogenic analysis revealed that ACO proteins were clustered into three groups (Houben and Van de Poel, 2019). The amino acid sequences of the three genes were extremely similar, and they clustered into type 1 (Supplementary Fig. S4).

Ethylene production and ACS and ACO transcript levels in the gynoecium and receptacle during natural senescence

Ethylene production in the gynoecium was relatively high on day 0 , and they decreased over the first 3 days before increasing on day 4 (Fig. 2). Ethylene production in receptacle changed similarly to that in gynoecium.

In the gynoecium, DgACS1 had the highest transcript levels among the three ACS genes at harvest, whereas its levels decreased during the first 3 days and increased thereafter (Fig. 3). DgACS2 transcript level in gynoecium gradually increased during senescence, and DgACS3 transcript level markedly increased from day 4. In receptacle, $D g A C S 2$ transcript level was highest on day 0 among the three ACS transcripts, but its level decreased during senescence. DgACS1 transcript level was relatively high on day 0 , and it decreased over the first 3 days before increasing on day 4. DgACS3 transcript level increased during senescence.

In the gynoecium, $D g A C O 1$ transcript level was much higher than those of the other two $A C O$ genes on day 0 , and it increased during senescence (Fig. 4). DgACO2 transcript level in the gynoecium gradually increased during senescence, whereas $D g A C O 3$ transcript level decreased during the first 5 days before increasing thereafter. In receptacle, $D g A C O 1$ had much higher transcript level than the other two $A C O$ genes on day 0 , and its level increased over the first 5 days and decreased thereafter. DgACO2 level was 
almost constant during the first 4 days before increasing thereafter. $D g A C O 3$ level increased during senescence.

Ethylene production and ACS and ACO transcript levels of gynoecium and receptacle after exposure to ethylene

Exposure to ethylene accelerated sepal abscission, and the sepals abscised within $24 \mathrm{~h}$. Ethylene production was more strongly increased in receptacle than in gynoecium after $8 \mathrm{~h}$ of ethylene exposure (Fig. 5).

In gynoecium, exposure to ethylene increased DgACS1 and DgACS2 transcript levels at most time points (Fig. 6). However, ethylene exposure only slightly affected DgACS3 transcript level. In receptacle, DgACS2 transcript level was highest among the three genes and higher after ethylene treatment than in the control at all time points. DgACS1 transcript level was not noticeably increased by ethylene treatment versus control. DgACS3 transcript level was decreased by ethylene treatment at all time points, and its level was lowest among the three transcripts.

In gynoecium, $D g A C O 1$ transcript levels were highest among the three transcripts, but ethylene exposure only slightly increased its level (Fig. 7). Ethylene exposure did not increase DgACO2 and DgACO3 transcript levels. In receptacle, $D g A C O 1$ transcript level was increased by ethylene treatment at all time points. $D g A C O 2$ transcript level was not increased by ethylene treatment, whereas DgACO3 transcript level was markedly increased by ethylene exposure.

\section{Effect of pollination on sepal abscission and pollen tube growth}

D. grandiflorum flowers are protandrous, and the gynoecium matured 3 or 4 days after anthesis under the present experimental conditions. Pollination accelerated sepal abscission, which was observed within 24 $\mathrm{h}$ after pollination. Pollen tube growth in gynoecia was observed via fluorescent microscopy. Many pollen tubes reached the ovary $6 \mathrm{~h}$ after pollination (Supplementary Fig. S5).

Ethylene production and ACS and ACO transcript levels in gynoecium and receptacle in unpollinated and pollinated flowers

Ethylene production was extremely low in unpollinated whole flowers throughout the experimental period. Similarly, ethylene production in gynoecium and receptacle was also extremely low in unpollinated flowers. Pollination increased ethylene production in the whole flower. Similarly, pollination markedly increased ethylene production in gynoecium, and the two ethylene peaks were observed after pollination (Fig. 8). Pollination increased ethylene production in receptacles, with production peaking at $8 \mathrm{~h}$ after pollination. 
In gynoecium, DgACS1 transcript level was slightly increased by pollination, whereas those of the other ACS genes were not increased (Fig. 9). In the receptacle, DgACS2 transcript level was increased by pollination, but $D g A C S 1$ and $D g A C S 3$ transcript levels were not altered.

In gynoecium, DgACO1 transcript level, which was highest among the three transcripts, was increased by pollination (Fig. 10). However, the levels of the other two ACO transcript levels were not increased by pollination. In receptacle, $D g A C O 1$ transcript level was higher in pollinated flowers than in unpollinated flowers at all time points. Although $D g A C O 2$ transcript level was slightly changed by pollination, $D g A C O 3$ transcript level was markedly increased by pollination.

\section{Discussion}

Delphinium flowers are highly sensitive to ethylene and the sepals abscise during senescence (Ichimura et al. 2009). In this study, we isolated three ACS and three ACO genes from D. grandiflorum, and the expression analysis in gynoecium and receptacle was performed during natural senescence and following ethylene exposure and pollination. ACS and $A C O$ gene expression was differently regulated in the gynoecium and receptacle.

\section{Ethylene production of gynoecium and receptacle}

Although ethylene production in gynoecium and receptacle at harvest was relatively high, its production increased in these organs during senescence (Fig. 2). This result somewhat differed from that in $D$. belladonna, in which ethylene production is relatively low at harvest in gynoecium and receptacle (Ichimura et al. 2009). The difference of ethylene production at harvest may be attributable to the different physiological properties of these species.

The trends of ethylene production in whole flowers following ethylene exposure and pollination differed from those in gynoecium and receptacle (Figs. 5 and 8). The sum of the gynoecium and receptacle fresh weight was one-tenth of that of the whole flower. Although ethylene production in floral organs other than gynoecium and receptacle was extremely low during natural senescence (Ichimura et al. 2009), ethylene production may decrease in these organs following ethylene exposure and pollination, resulting in differences in ethylene production between the whole flower and the two organs.

\section{ACS and ACO gene expression during natural flower senescence}

In the carnation gynoecium, DCACS2 and DCACO1 transcript levels increase during senescence (ten Have and Woltering 1997; Jones and Woodson 1999). Similarly, SIACS1A transcript levels increased during senescence in the tomato (Llop-Tous et al. 2000). In petals displaying abscission, changes in ACS and $A C O$ transcript levels in gynoecium during natural senescence have only been reported for geranium, but no substantial increases in their transcript levels were observed (Clark et al. 1997). In the present study, the peak DgACS3 transcript level was much higher than those of the other ACS transcripts (Fig. 3). 
$D g A C 01$ transcript levels were higher than those of the other $A C O$ transcripts (Fig. 4). These results suggest that $D g A C S 3$ and $D g A C O 1$ expression appears to largely contribute to increased ethylene production in gynoecium.

To date, the expression of $A C S$ and $A C O$ genes in receptacle has only been investigated in carnation (Jones and Woodson 1999) and rose (Xue et al. 2008), but no obvious changes in these transcript levels were observed during senescence. In receptacle, DgACS2 transcript level was much higher than those of the other ACS transcripts on day 0, but its level decreased during senescence (Fig. 3). Conversely, DgACS1 and DgACS3 transcript levels increased during senescence. Similarly, the levels of the three $A C O$ transcripts increased during senescence, although some differences were observed (Fig. 4). Thus, the expression of these $A C S$ and $A C O$ genes appears to contribute to ethylene production in receptacle.

\section{ACS and ACO gene expression following ethylene exposure}

Exposure to ethylene accelerated sepal abscission, which is consistent with previous findings (Ichimura et al. 2000, 2009). Ethylene exposure more strongly increased ethylene production in receptacle than in gynoecium (Fig. 5), suggesting that the responsiveness of ethylene production to ethylene exposure is higher in receptacle than in gynoecium. The receptacle, but not the gynoecium, is connected to sepals in D. grandiflorum flowers (Fig. 1). Thus, sepal abscission following ethylene exposure may be induced by increased ethylene production of the receptacle.

$A C S$ and $A C O$ gene expression in receptacle following ethylene exposure has only been reported in carnation (Jones and Woodson 1999) and rose (Xue et al. 2008). Among these genes, only RhACS2 expression was slightly increased by ethylene exposure (Xue et al. 2008). DgACS2 and DgACO3 transcript levels in the receptacle were relatively high, and they were markedly increased by ethylene exposure (Figs. 6 and 7). This finding suggests that DgACS2 and DgACO3 may contribute to increased ethylene production in receptacle associated with sepal abscission.

$D g A C S 1$ and DgACS2 transcript levels in gynoecium were increased by ethylene exposure, whereas the expression of $D g A C S 3$ and the three $A C O$ genes did not increase (Figs. 6 and 7). These results suggest that $D g A C S 1$ and $D g A C S 2$ contribute to increased ethylene production in gynoecium in response to ethylene exposure. To date, the expression of $A C S$ and $A C O$ genes in pistil or gynoecium following ethylene exposure has been reported in carnation (Jones and Woodson 1997, 1999), petunia (Tang et al. 1994), rose (Xue et al. 2008), and tomato (Llop-Tous et al. 2000). In these plants, the transcript levels of some ACS genes, including DCACS2 (Jones and Woodson 1997) and SIACS2 (Llop-Tous et al. 2000) and ACO genes, including PhACO1 (Tang et al. 1994), are increased by exposure to ethylene.

\section{ACS and ACO gene expression in pollinated flowers}

As reported in many plants, including Digitalis (Stead and Moore 1979), geranium (Clark et al. 1997) and torenia (Goto et al. 1999), pollination accelerated sepal abscission in D. grandiflorum. Ethylene production in gynoecium markedly increased $4 \mathrm{~h}$ after pollination (Fig. 8). However, only DgACO1 transcript level in the gynoecium was increased by pollination (Fig. 10). In Delphinium gynoecium, ACO activity at anthesis 
is relatively high (Ichimura et al. 2009). The pollen of some plants, including petunia, contains large amounts of ACC (Whitehead et al. 1983). In petunia flowers, an early increase in ethylene production is associated with the ACC content in pollen (Singh et al. 1992). We confirmed that pollen tubes reached ovary $6 \mathrm{~h}$ after pollination (Supplementary Fig. S5). Thus, marked increase in ethylene production in gynoecium may be attributed to pollen-born ACC, which is converted to ethylene by ACO activity. Alternatively, other $A C S$ and $A C O$ genes may be specifically induced by pollination, although these types of $A C S$ and $A C O$ genes have not yet been identified in other plant species.

The coordination of senescence processes in pollinated flowers is involved in interorgan signaling (Jones and Woodson 1997). The transmissible factor for this signaling has been proposed to be ethylene (Woltering et al. 1995) or ACC (Reid et al. 1984). Ethylene production in receptacle increased $4 \mathrm{~h}$ after pollination (Fig. 8), suggesting that pollination generates some transmissible factor that induces ethylene production of the receptacles because receptacle lies below the gynoecium. Increased ethylene production was associated with increases in DgACO1 and DgACO3 transcript levels in receptacle (Fig. 10). Thus, ethylene produced by the gynoecium in response to pollination may increase the expression of these genes, resulting in increased ethylene production in receptacle.

\section{Significance of the receptacle and possible model for sepal abscission}

The significance of gynoecium to petal senescence has been emphasized for petal wilting in petunia (Whitehead et al. 1984) and carnation (Shibuya et al. 2000) and for petal abscission in Digitalis (Stead and Moore 1983) and geranium (Clark et al. 1997). Although changes in some ACS and ACO transcript levels in receptacle were reported in carnation (Jones and Woodson 1999) and rose (Xue et al. 2008), the significance of this organ to petal wilting was only mentioned by Hsieh and Sacalis (1986), who reported ACC levels in receptacle during senescence in cut carnation. The significance of receptacle to sepal abscission has been described only for Delphinium flowers (Ichimura et al. 2009). In our study, ethylene exposure and pollination increased ethylene production more strongly in receptacle than in gynoecium, and this finding was associated with marked increases in some ACS and ACO transcript levels in receptacle. These results suggest the significance of receptacle to sepal abscission. Thus, the receptacle is likely to be a primarily organ that regulates sepal abscission in Delphinium.

We thus propose a model for sepal abscission based on the present results (Fig. 11). During natural flower senescence, increases in $D g A C S 1, D g A C S 3, D g A C O 1$ and $D g A C O 3$ transcript levels are primarily responsible for ethylene production in receptacle, leading to sepal abscission. However, whether increase in ethylene production in gynoecium affects ethylene biosynthesis is unclear. Exposure to ethylene increases DgACS2 and DgACO3 transcript levels in receptacle, leading to sepal abscission. Receptacle should directly respond to exogenous ethylene. Pollination increases ethylene production in gynoecium without inducing $A C S$ and $A C O$ gene expression. The increase in ethylene production in gynoecium may lead to increased $D g A C S 2$ and $D g A C O 3$ transcript levels in receptacle, resulting in sepal abscission. 


\section{Conclusion}

Ethylene production in gynoecium and receptacle in $D$. grandiflorum flowers somewhat increased during natural senescence. Three ACS genes (DgACS1, DgACS2, and DgACS3) and three ACO genes (DgACO1, $D g A C O 2$, and $D g A C O 3$ ) were cloned. The transcript levels of the $A C S$ and $A C O$ genes in these organs increased during senescence, excluding $D g A C S 2$ in receptacle. Exposure to ethylene more strongly increased ethylene production in receptacle than in gynoecium and induced sepal abscission. DgACS1 transcript level in gynoecium and $D g A C S 2$ and $D g A C O 3$ transcript levels in receptacle were increased by ethylene exposure. Pollination increased ethylene production of gynoecium and receptacle and markedly accelerated sepal abscission. However, pollination only slightly affected ACS and ACO transcript levels in gynoecium, whereas $D g A C O 3$ transcript level in receptacle was markedly increased. These results suggest that increases in the transcript levels of some $A C S$ and $A C O$ genes in gynoecium and receptacle may contribute to the increases in ethylene production associated with sepal abscission. Ethylene exposure and pollination more strongly increased the expression of these genes in receptacle than in gynoecium, suggesting the significance of receptacle to sepal abscission.

\section{Declarations}

\section{Author contribution statement}

$\mathrm{MO}, \mathrm{KS}$ and $\mathrm{KI}$ conceived and designed the research. MO and AS performed physiological experiments. $\mathrm{MO}$ and TN performed molecular experiments. KI wrote the manuscript. All authors read and approved the manuscript.

\section{Compliance with ethical standards}

Conflict of interest The authors declare that they have no competing interests.

Data Availability Statement The data that supports the findings of this study are available in the supplementary material of this article.

\section{References}

1. Argueso CT, Hansen M, Kieber JJ (2007) Regulation of ethylene biosynthesis. J Plant Growth Regul 26:92-105. https://doi.org/10.1007/s00344-007-0013-5

2. Clark DG, Richards C, Hilioti Z, Lind-Iversen S, Brown K (1997) Effect of pollination on accumulation of ACC synthase and ACC oxidase transcripts, ethylene production and flower petal abscission in geranium (Pelargonium $\times$ hortorum L.H. Bailey). Plant Mol Biol 34:855-865 https://doi.org/10.1023/A:1005877809905

3. Do YY, Thay TS, Chang TW, Huang PL (2005) Molecular cloning and characterization of a novel 1aminocyclopropane-1-carboxylate oxidase gene involved in ripening of banana fruits. J Agric Food Chem 53:8239-8247 https://doi.org/10.1021/jf051224+ 
4. Gillisen LJW, Hoekstra FA (1984) Pollination-induced corolla wilting in Petunia hybrida rapid transfer through the style of a wilting-inducing substance. Plant Physiol 75:496-498.

https://doi.org/10.1104/pp.75.2.496

5. Goto R, Aida R, Shibata M, Ichimura K (1999) Role of ethylene on flower senescence of Torenia. J Jpn Soc Hort Sci 68:263-268. https://doi.org/10.2503/jjshs.68.263

6. Hilioti Z, Richards C, Brown KM (2000) Regulation of pollination-induced ethylene and its role in petal abscission of Pelargonium $\times$ hortorum. Physiol Plant 109:322-332. https://doi.org/10.1034/j.13993054.2000.100314.x

7. Houben M, Van de Poel B (2019) 1-Aminocyclopropane-1-carboxylic acid oxidase (ACO): the enzyme that makes the plant hormone ethylene. Front Plant Sci 10:695.

https://doi.org/10.3389/fpls.2019.00695

8. Hsieh YC, Sacalis J (1986) Levels of ACC in various floral portions during aging of cut carnations. J Am Soc Hort Sci 111:942-944

9. Ichimura K, Goto R (2000) Acceleration of senescence by pollination of cut 'Asuka-no-nami' Eustoma flowers. J Jpn Soc Hort Sci 69:166-170. https://doi.org/10.2503/jjshs.69.166

10. Ichimura K, Kohata K, Goto R (2000) Soluble carbohydrate in Delphinium and their influence on sepal abscission in cut flowers. Physiol Plant 108:307-313. https://doi.org/10.1034/j.13993054.2000.108003307.x

11. Ichimura K, Shimamura M, Hisamatsu T (1998) Role of ethylene in senescence of cut Eustoma flowers. Postharvest Biol Technol 14:193-198. https://doi.org/10.1016/S0925-5214(98)00039-8

12. Ichimura K, Shimizu-Yumoto H, Goto R (2009) Ethylene production by the gynoecium and receptacle is associated with sepal abscission in cut Delphinium flowers. Postharvest Biol Technol 52:267-272. https://doi.org/10.1016/j.postharvbio.2008.12.008

13. Jackson MB, Campbell DJ (1975) Movement of ethylene from roots to shoots, a factor in the responses of tomato plants to waterlogged soil conditions. New Phytol 74:397-406. https://doi.org/10.1111/j.1469-8137.1975.tb01350.x

14. Jones ML (2003) Ethylene biosynthetic genes are differentially regulated by ethylene and ACC in carnation styles. Plant Growth Regul 40:129-138. https://doi.org/10.1023/A:1024241006254

15. Jones ML, Woodson WR (1997) Pollination-induced ethylene in carnation. Role of stylar ethylene in corolla senescence. Plant Physiol 115:205-212. https://doi.org/10.1104/pp.115.1.205

16. Jones ML, Woodson WR (1999) Differential expression of three members of the 1aminocyclopropane-1-carboxylate synthase gene family in carnation. Plant Physiol 119:755-764. https://doi.org/10.1104/pp.119.2.755

17. Kende H (1993) Ethylene biosynthesis. Annu Rev Plant Physiol Mol Biol 44:283-307. https://doi.org/10.1146/annurev.pp.44.060193.001435

18. Kuroda S, Hakata M, Hirose Y, Shiraishi M, Abe S (2003) Ethylene production and enhanced transcription of an ethylene receptor gene, ERS1, in Delphinium during abscission of florets. Plant Physiol Biochem 41:812-820. https://doi.org/10.1016/S0981-9428(03)00115-3 
19. Kuroda S, Hirose Y, Shiraishi M, Davies E, Abe S (2004) Co-expression of an ethylene receptor gene, ERS1, and ethylene signaling regulator gene, CTR1, in Delphinium during abscission of florets. Plant Physiol Biochem 42:745-751. https://doi.org/10.1016/j.plaphy.2004.07.006

20. Lee MM, Lee SH, Park KY (1997) Effects of spermine on ethylene biosynthesis in cut carnation (Dianthus caryophyllus L.) flowers during senescence. J Plant Physiol 151:68-73. https://doi.org/10.1016/S0176-1617(97)80038-7

21. Lin Z, Zhong S, Grierson D (2009) Recent advances in ethylene research. J Exp Bot 60:3311-3336. https://doi.org/10.1093/jxb/erp204

22. Llop-Tous I, Barry CS, Grierson D (2000) Regulation of ethylene biosynthesis in response to pollination in tomato flowers. Plant Physiol 123:971-978. https://doi.org/10.1104/pp.123.3.971

23. Luu-The V, Paquet N, Calvo E, Cumps J (2005) Improved real-time RT-PCR method for highthroughput measurements using second derivative calculation and double correction. Biotechniques 38:287-293. https://doi.org/10.2144/05382RR05

24. Momonoi K, Shoji K, Yoshida K (2007) Cloning and characterization of ACC oxidase genes from tulip. Plant Biotechnol 24:241-246. https://doi.org/10.5511/plantbiotechnology.24.241

25. Nakatsuka A, Murachi S, Okunishi H, Shiomi S, Nakano R, Kubo Y, Inaba A (1998) Differential expression and internal feedback regulation of 1-aminocyclopropene-1-carboxylate synthase, 1aminocyclopropene-1-carboxylate oxidase, and ethylene receptor genes in tomato fruit during development and ripening. Plant Physiol 118:1295-1305. https://doi.org/10.1104/pp.118.4.1295

26. Nichols R (1966) Ethylene production during senescence of flowers. J Hort Sci 41:279-290. https://doi.org/10.1080/00221589.1966.11514176

27. O'Neill SD, Nadeau JA, Zhang XS, Bui AQ, Halevy AH (1993) Interorgan regulation of ethylene biosynthetic genes by pollination. Plant Cell 5:419-432. https://doi.org/10.1105/tpc.5.4.419

28. Porat R, Halevy AH, Serek M, Borochov A (1995) An increase in ethylene sensitivity following pollination in the initial event triggering an increase in ethylene production and enhanced senescence of Phalaenopsis orchid flowers. Physiol Plant 93:778-784. https://doi.org/10.1111/j.13993054.1995.tb05131.x

29. Reid MS, Fujino DW, Hoffman NE, Whitehead CS (1984) 1-Aminocyclopropane-1-

30. carboxylic acid (ACC) - The transmitted stimulus in pollinated flowers? J. Plant Growth Regul 3:189-196 https://doi.org/10.1007/BF02042003

31. Shibuya K, Yoshioka T, Hashiba T, Satoh S (2000) Role of the gynoecium in natural senescence of carnation (Dianthus caryophyllus L.) flowers. J Exp Bot 51:2067-2073.

https://doi.org/10.1093/jexbot/51.353.2067

32. Shimizu-Yumoto H, Ichimura K (2012) Effects of ethylene, pollination, and ethylene inhibitor treatments on flower senescence of gentians. Postharvest Biol Technol 63:111-115. https://doi.org/10.1016/j.postharvbio.2011.08.009

33. Singh A, Evensen KB, Kao Th (1992) Ethylene synthesis and floral senescence following compatible and incompatible pollinations in Petunia inflata. Plant Physiol 99:38-45. 
http://www.plantphysiol.org/content/99/1/38

34. Stead AD, Moore KG (1979) Studies on flower longevity in Digitalis. Pollination induced corolla abscission in Digitalis flowers. Planta 146:409-414. https://doi.org/10.1007/BF00380853

35. Stead AD, Moore KG (1983) Studies on flower longevity in Digitalis. The role of ethylene in corolla abscission. Planta 157:15-21 https://doi.org/10.1007/BF00394535

36. Tanase K, Ichimura K (2006) Expression of ethylene receptors DI-ERS1-3 and DI-ERS2, and ethylene response during flower senescence in Delphinium. J Plant Physiol 163:1159-1166. https://doi.org/10.1016/j.jplph.2005.12.003

37. Tang X, Gomes AMTR, Bhatia A, Woodson WR (1994) Pistil specific and ethylene-regulated expression of 1-aminocyclopropene-1-carboxylate oxidase genes on petunia flower. Plant Cell 6:1227-1239. https://doi.org/10.1105/tpc.6.9.1227

38. ten Have A, Woltering EJ (1997) Ethylene biosynthetic genes are differentially expressed during carnation (Dianthus caryophyllus L.) flower senescence. Plant Mol Biol 34:89-97. https://doi.org/10.1023/A:1005894703444

39. Wang H, Woodson WR (1991) A flower senescence-related mRNA from carnation shares sequence similarity with fruit ripening-related mRNAs involved in ethylene biosynthesis. Plant Physiol 96:1000-1001. https://doi.org/10.1104/pp.96.3.1000

40. Whitehead CS, Fujino DW, Reid MS (1983) Identification of the ethylene precursor, 1aminocyclopropane-1-carboxylic acid (ACC), in pollen. Sci Hortic 21:291-297. https://doi.org/10.1016/0304-4238(83)90103-6

41. Whitehead CS, Halevy AH, Reid MS (1984) Roles of ethylene and 1-aminocyclopropane-1-carboxylic acid in pollination and wound-induced senescence of Petunia hybrida flowers. Physiol Plant 61:643648. https://doi.org/10.1111/j.1399-3054.1984.tb05184.x

42. Woltering EJ, Somhorst D, de Beer CA (1993) Roles of ethylene production and sensitivity in senescence of carnation flower (Dianthus caryophyllus) cultivars White Sim, Chinera and Epomeo. J Plant Physiol 141:329-335. https://doi.org/10.1016/S0176-1617(11)81743-8

43. Woltering EJ, Somhorst $D$, van der Veer $P(1995)$ The role of ethylene in interorgan signaling during flower senescence. Plant Physiol 109:1219-1225. https://doi.org/10.1104/pp.109.4.1219

44. Woltering EJ, van Doorn WG (1988) Role of ethylene in senescence of petals-morphological and taxonomical relationships. J Exp Bot 39:1605-1616. https://doi.org/10.1093/jxb/39.11.1605

45. Woodson WR, Park KY, Drory A, Larsen PB, Wang H (1992) Expression of ethylene biosynthetic pathway transcripts in senescing carnation flowers. Plant Physiol 99:526-532. https://doi.org/10.1104/pp.99.2.526

46. Xue J, Li Y, Tan H, Yang F, Ma N, Gao J (2008) Expression of ethylene biosynthetic and receptor genes in rose floral tissues during ethylene-enhanced flower opening. J Exp Bot 59:2161-2169. https://doi.org/10.1093/jxb/ern078

47. Yamada T, Ichimura K, van Doorn WG (2007) Relationship between petal abscission and programmed cell death in Prunus yedoensis and Delphinium belladonna. Planta 226:1195-1205. 
https://doi.org/10.1007/s00425-007-0566-3

48. Yang SF, Hoffman NE (1984) Ethylene biosynthesis and its regulation in higher plants. Ann Rev Plant Physiol 35:155-189. https://doi.org/10.1146/annurev.pp.35.060184.001103

49. Zeroni M, Jerie PH, Hall MA (1977) Studies on the movement and distribution of ethylene in Vicia faba L. Planta 134:119-125. https://doi.org/10.1007/BF00384960

\section{Figures}

\section{Figure 1}

Morphology of Delphinium grandiflorum flowers. A. Flower spikes. The scale bar represents $10 \mathrm{~cm}$. B. Flower. The scale bar represents $1 \mathrm{~cm}$. C. Sepal, gynoecium and receptacle. The scale bar represents 1 $\mathrm{cm}$. D. Gynoecium and receptacle. The scale bar represents $0.5 \mathrm{~cm}$. 

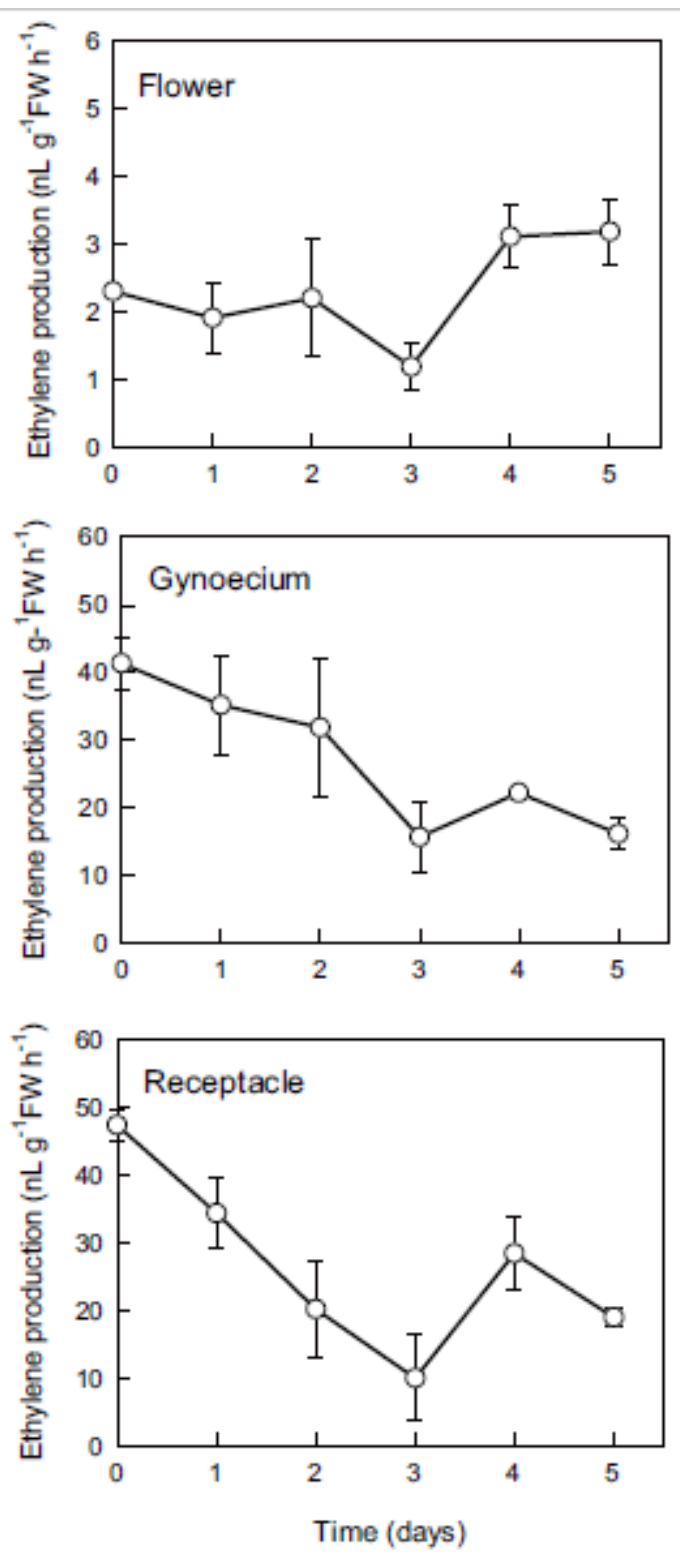

Figure 2

Ethylene production in flowers, gynoecium and receptacle during natural flower senescence. Values are means of five biological replicates $\pm \mathrm{SE}$. 

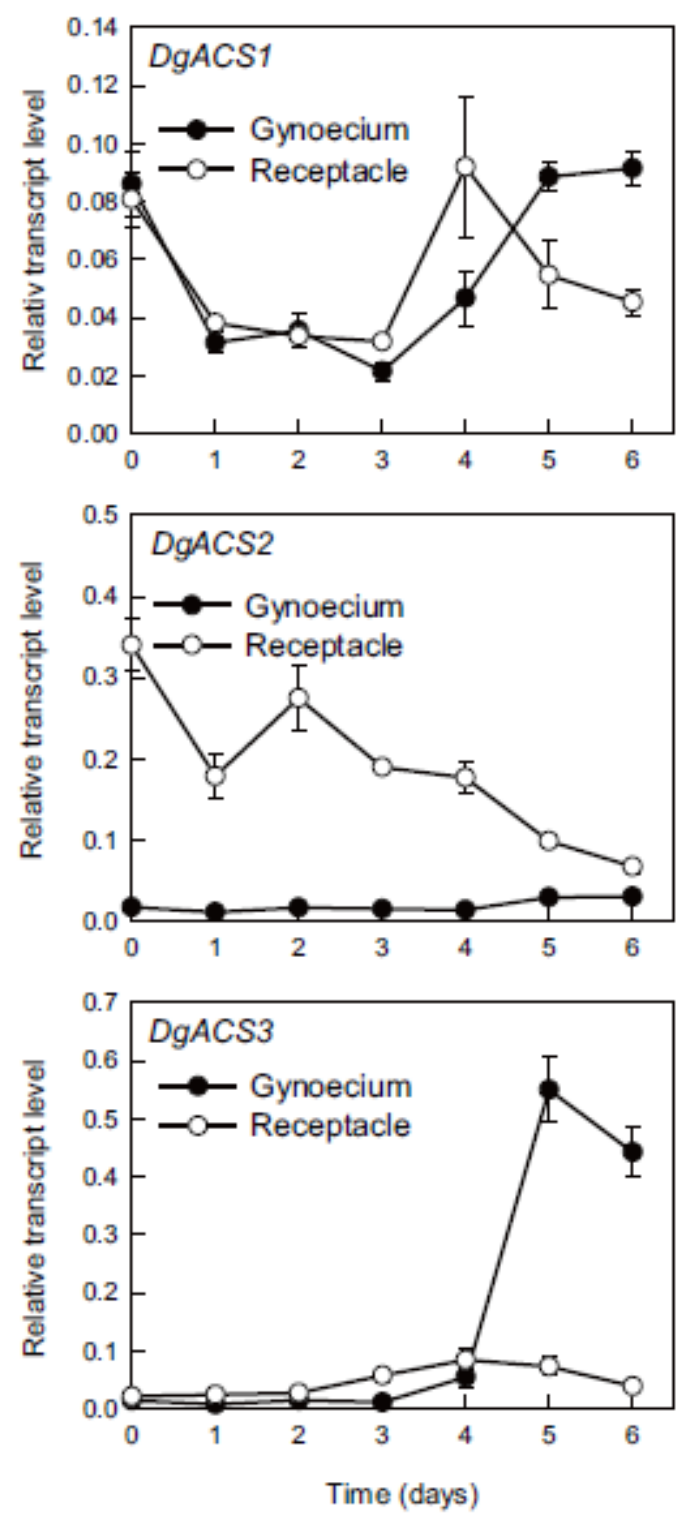

Figure 3

$D g A C S 1, D g A C S 2$ and $D g A C S 3$ transcript levels in gynoecium and receptacle during natural flowers senescence. Values are means of three biological replicates \pm SE. 

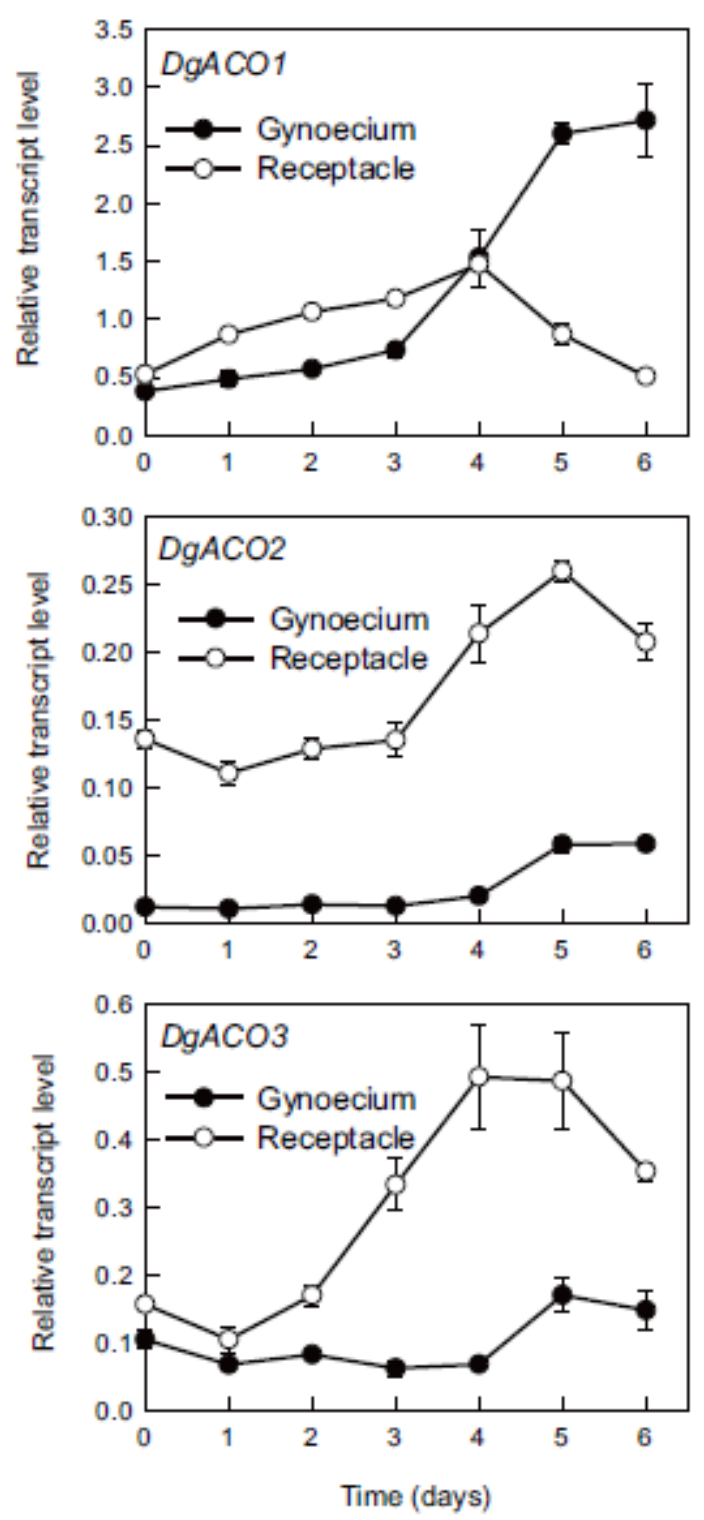

Figure 4

$D g A C 01, D g A C O 2$ and $D g A C O 3$ transcript levels in gynoecium and receptacle during natural flowers senescence. Values are means of three biological replicates \pm SE. 

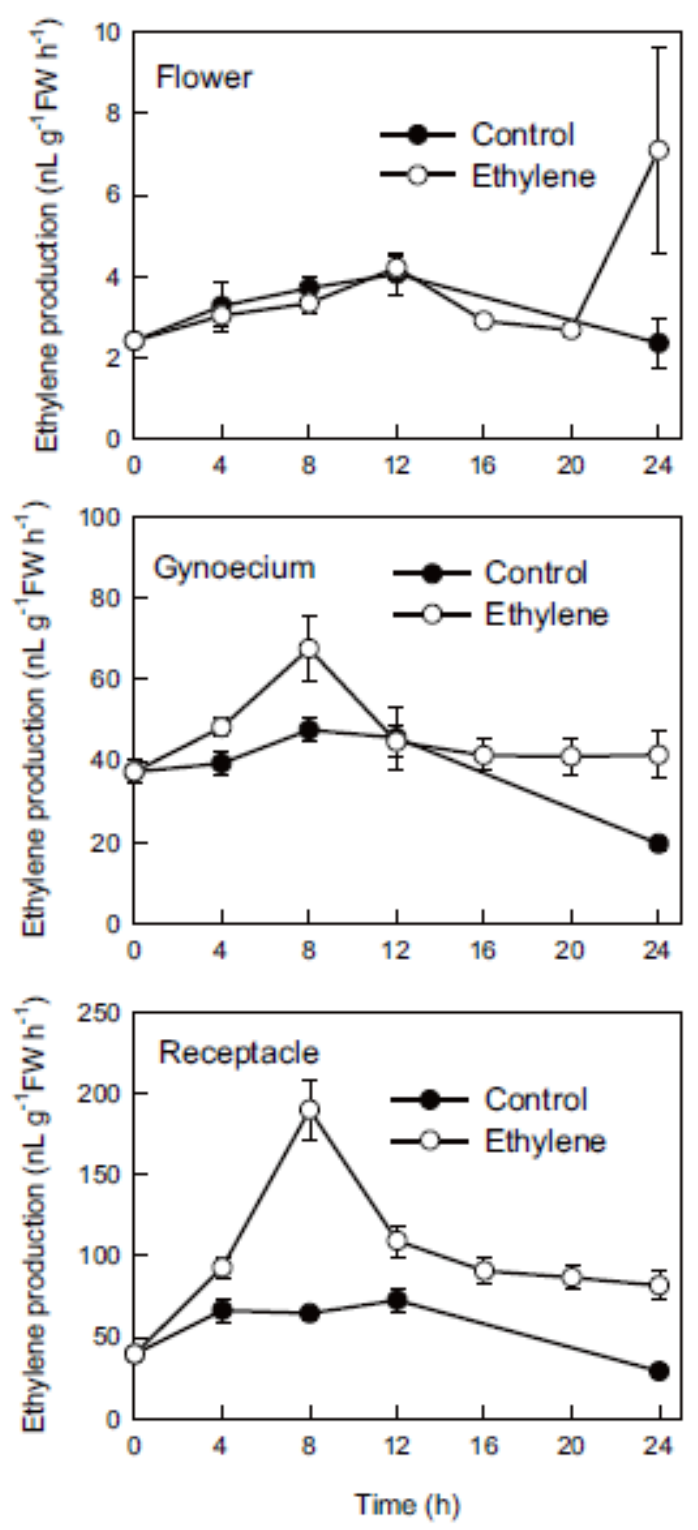

\section{Figure 5}

Ethylene production in flowers, gynoecium and receptacle during ethylene exposure. Values are means of five biological replicates \pm SE. 
A Gynoecium
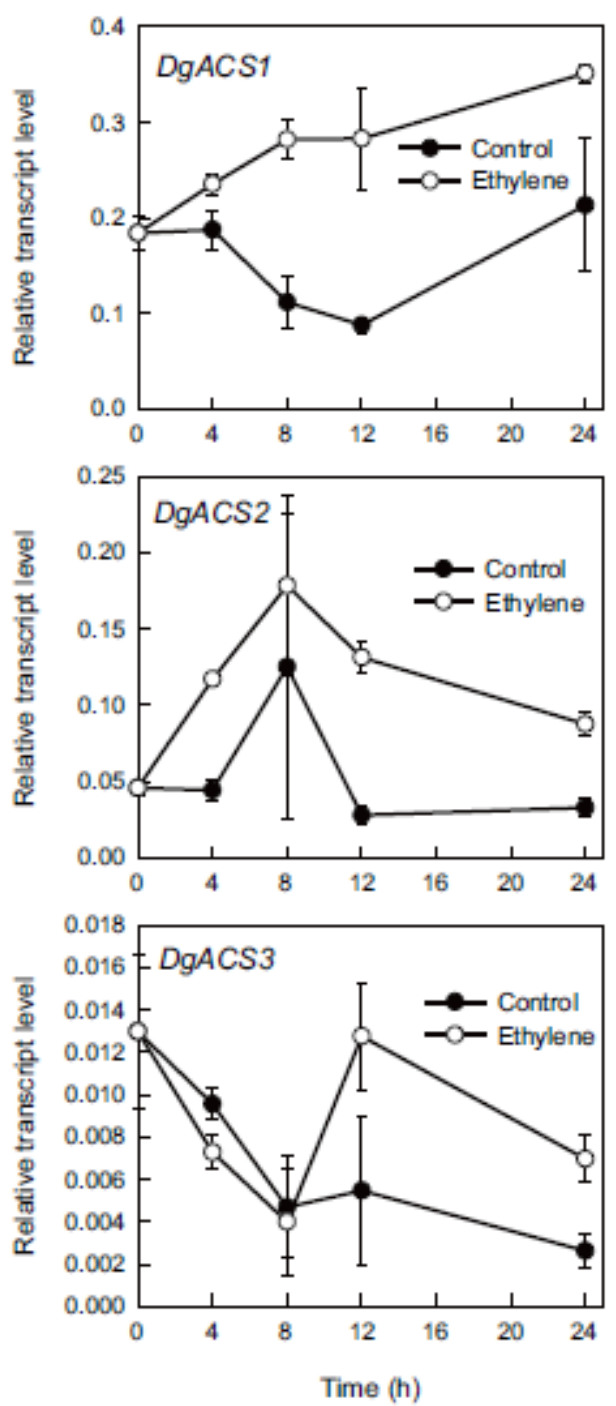

B Receptacle
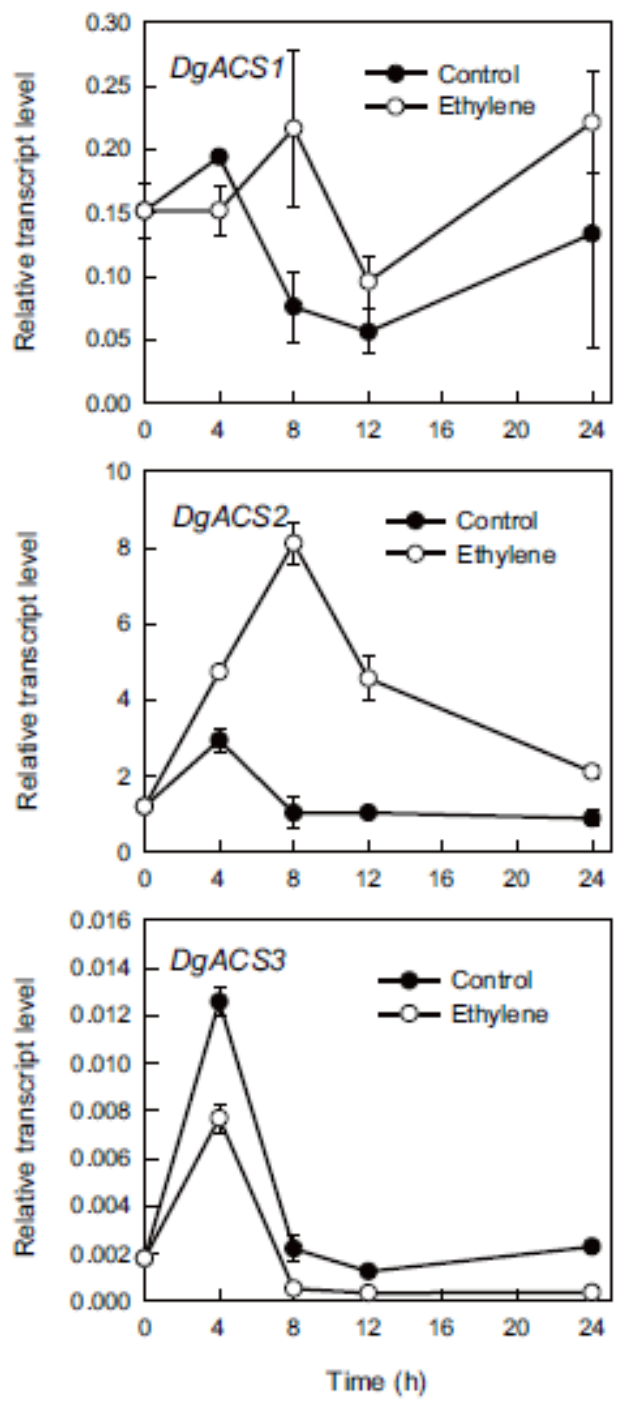

Figure 6

DgACS1, DgACS2 and DgACS3 transcript levels in gynoecium (A) and receptacle (B) during ethylene exposure. Values are means of three biological replicates \pm SE. 
A Gynoecium
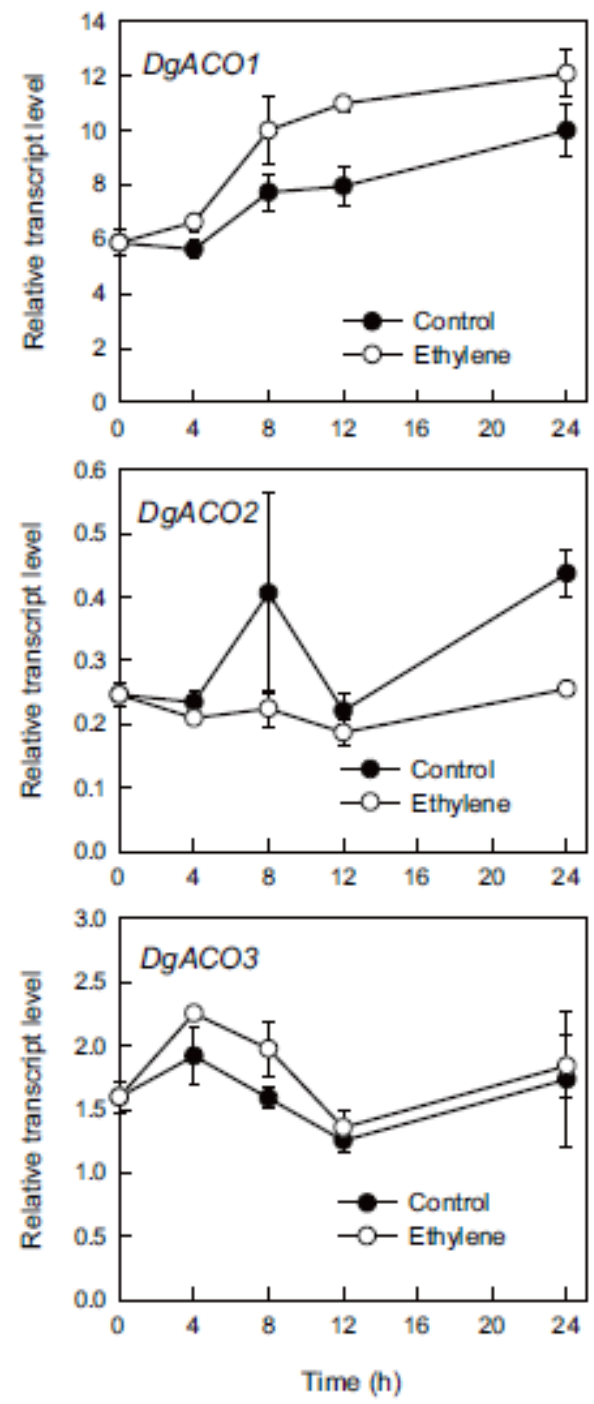

B Receptacle
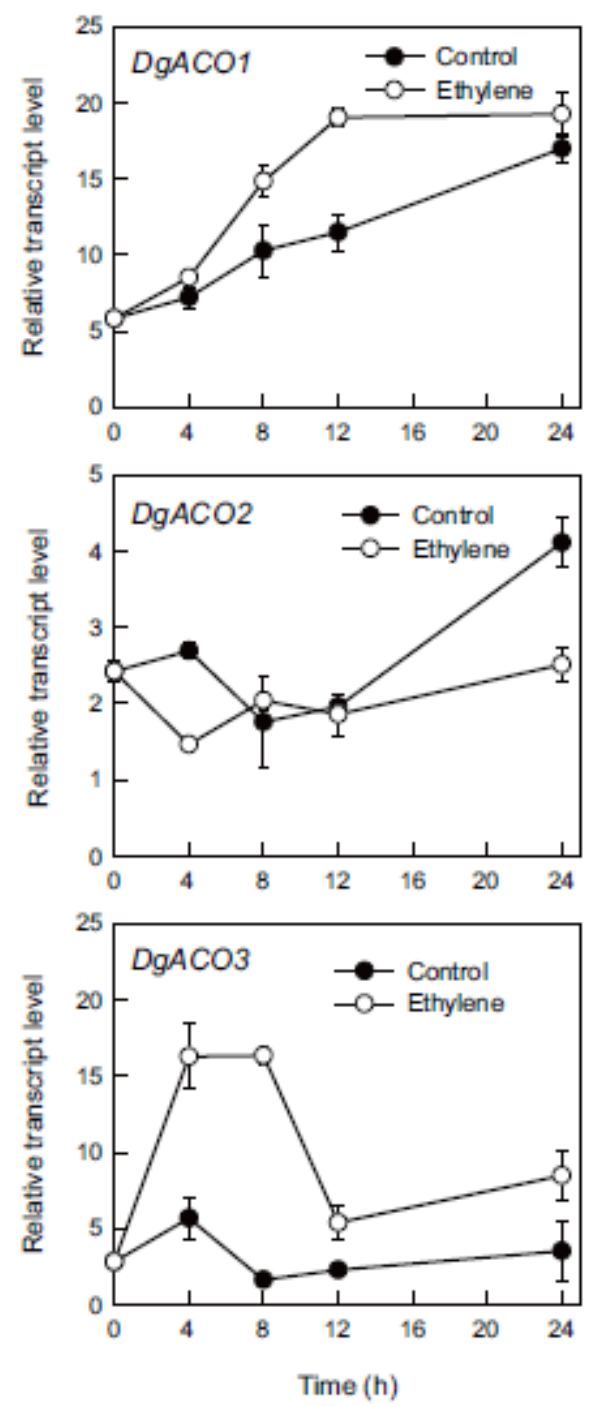

Figure 7

$D g A C 01, D g A C O 2$ and $D g A C O 3$ transcript levels in gynoecium (A) and receptacle (B) during ethylene exposure. Values are means of three biological replicates \pm SE.

\section{Figure 8}

Ethylene production in flowers, gynoecium and receptacle following pollination. Values are means of five biological replicates \pm SE.

Figure 9 
DgACS1, DgACS2 and DgACS3 transcript levels in gynoecium (A) and receptacle (B) following pollination. Values are means of three biological replicates \pm SE.

A Gynoecium
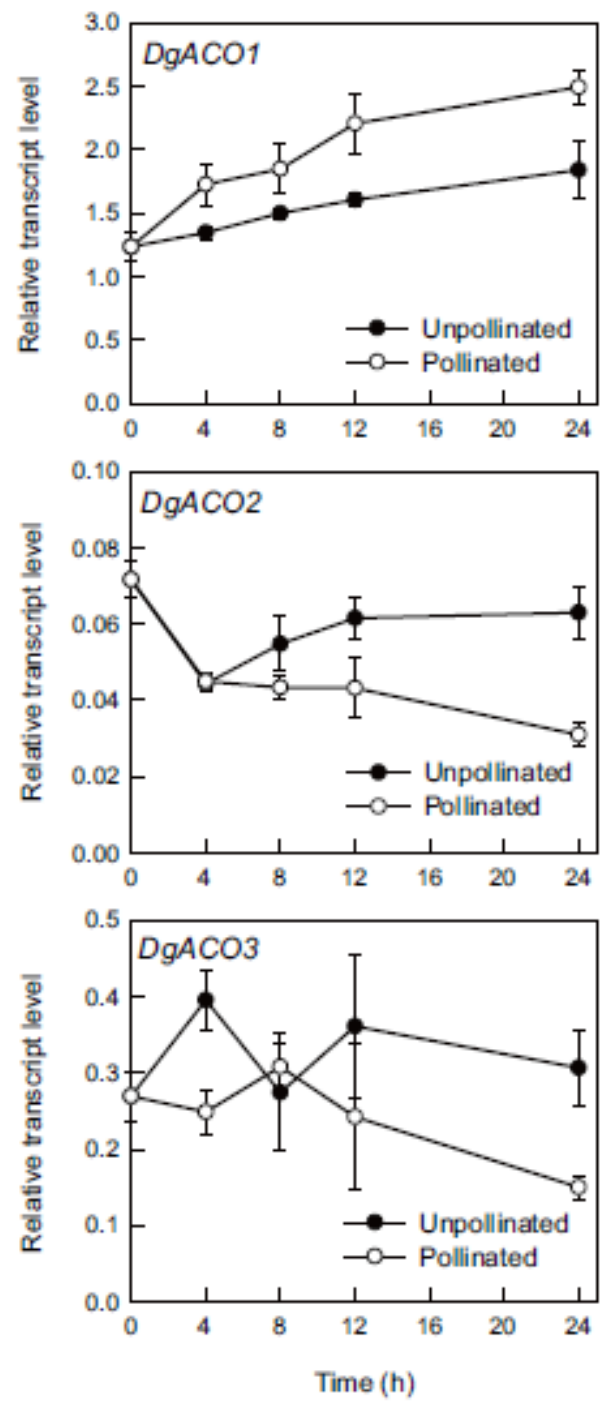

B Receptacle
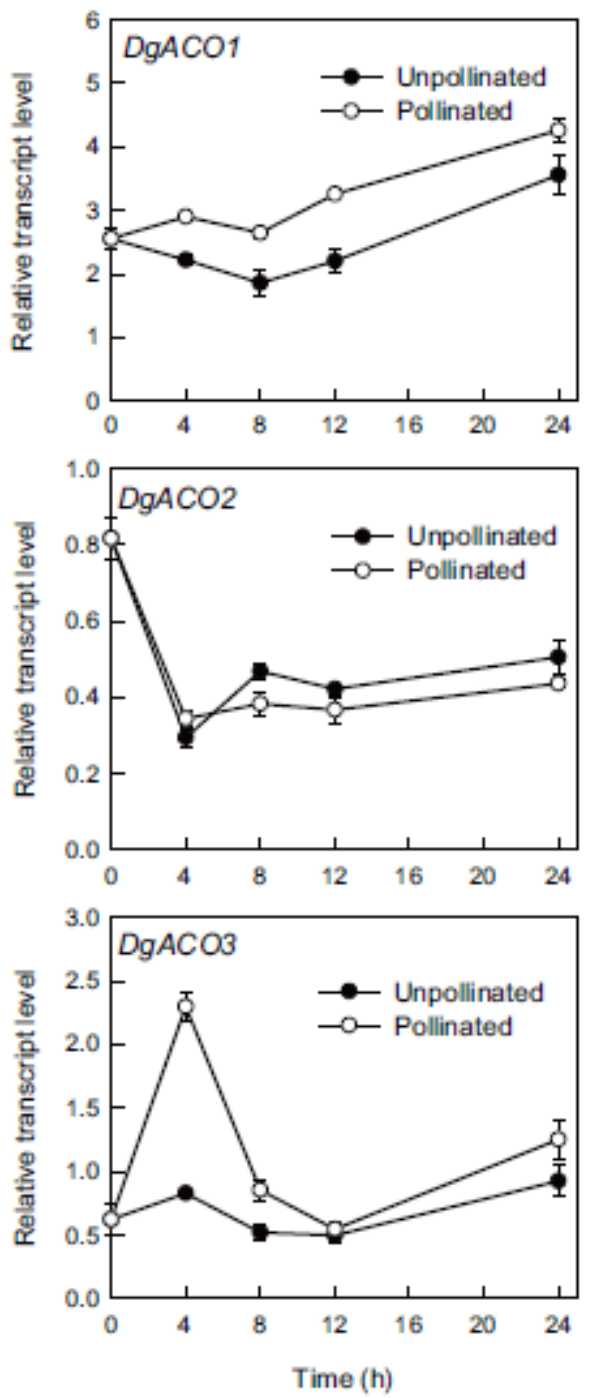

Figure 10

$D g A C 01, D g A C O 2$ and $D g A C O 3$ transcript levels in gynoecium (A) and receptacle (B) following pollination. Values are means of three biological replicates $\pm \mathrm{SE}$. 


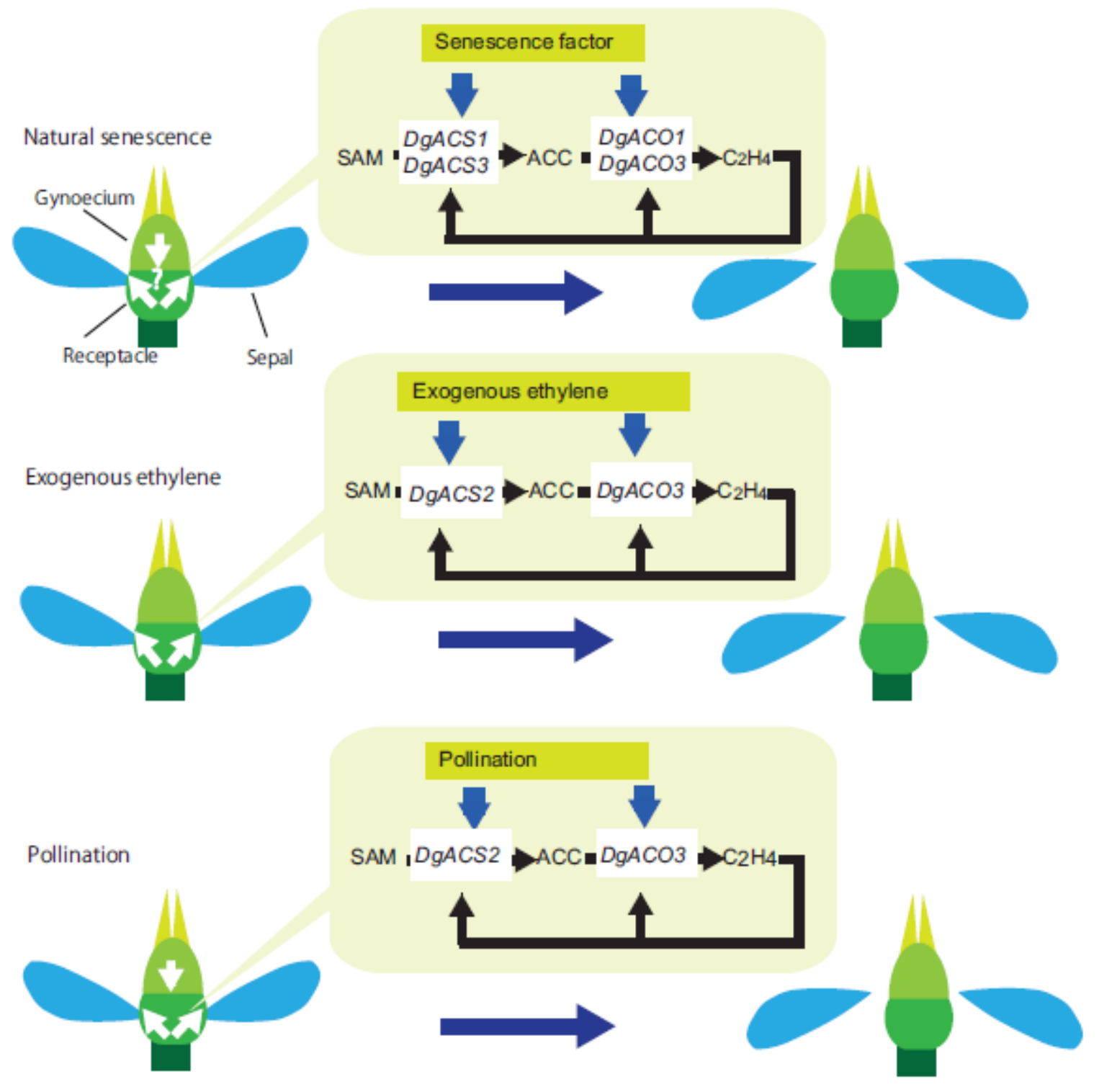

Figure 11

Proposed model for sepal abscission during natural senescence, following exposure to ethylene and pollination in $D$. grandiflorum. White arrows indicate ethylene production. Balloon diagrams indicate the regulation of ethylene biosynthesis in receptacle.

\section{Supplementary Files}

This is a list of supplementary files associated with this preprint. Click to download.

- Supplementarymaterial.pdf 